\title{
Performance Evaluation of Waste Stabilisation Ponds
}

\author{
O. P. Gopolang, M. W. Letshwenyo* \\ Department of Civil and Environmental Engineering, Faculty of Engineering and Technology, \\ Botswana International University of Science and Technology, Palapye, Botswana \\ Email: obenneg@gmail.com, ${ }^{*}$ letshwenyom@biust.ac.bw
}

How to cite this paper: Gopolang, O.P. and Letshweny M.W. (2018) Performance Evaluation of Waste Stabilisation Ponds. Journal of Water Resource and Protection, 10, 1129-1147.

https://doi.org/10.4236/jwarp.2018.1011067

Received: September 21, 2018

Accepted: November 19, 2018

Published: November 22, 2018

Copyright ( 92018 by authors and Scientific Research Publishing Inc. This work is licensed under the Creative Commons Attribution International License (CC BY 4.0).

http://creativecommons.org/licenses/by/4.0/

(c) (i) Open Access

\begin{abstract}
Waste stabilisation pond system has been used more especially in developing countries for sewage treatment. The objective of this study was to investigate the hydraulic and performance efficiency of Palapye waste stabilisation ponds. The hydraulic efficiency was evaluated through drogue, pond geometry and sludge accumulation assessment. The performance efficiency was evaluated through periodic sampling and analysis of physiochemical and bacteriological parameters of individual units and of the system as a whole. Except for the maturation ponds, the depth of the anaerobic pond had reduced from $4 \mathrm{~m}$ to $0.45 \mathrm{~m}$, for facultative ponds from $2.0 \mathrm{~m}$ to a range of 0.52 $\mathrm{m}-0.91 \mathrm{~m}$. The design hydraulic retention time of the system had reduced from 20 days to 7.1 days. The concentration of some physiochemical parameters in the effluent was $305 \mathrm{mg} \cdot \mathrm{L}^{-1}, 277$ Nephelometric Turbidity Units (NTU), $204 \mathrm{mg} \cdot \mathrm{L}^{-1}, 156 \mathrm{mg} \cdot \mathrm{L}^{-1}, 110 \mathrm{mg} \cdot \mathrm{L}^{-1}$, and $15 \mathrm{mg} \cdot \mathrm{L}^{-1}$ being total suspended solids, turbidity, nitrates, chemical oxygen demand, biochemical oxygen demand and phosphate respectively. These values were more than the standard limits of the country. Effluent total coliforms concentration was 3.6 $\log$ units and within the threshold of $4.3 \mathrm{log}$ units, faecal coliforms concentration was $3.5 \log$ units, slightly higher than the threshold of $3 \log$ units. Though Escherichia coli have no limits for discharge into other environments, the concentration in the effluent was reasonable at $2.5 \mathrm{log}$ units and also within irrigation limit of $3 \log$ counts. Palapye wastewater treatment system hydraulic efficiency is lower than the design criterion. The system was overall poor in physiochemical parameters removal but better in bacteriological removal.
\end{abstract}

\section{Keywords}

Hydraulic Efficiency, Waste Stabilisation Ponds, Length to Width Ratio, Pond Geometry 


\section{Introduction}

The growing investment in water supply and reticulation in Botswana has resulted in many households' connections and large quantities of wastewater generated which needs adequate treatment to meet national standards before disposal into the receiving environment. Treatment to required standards has been a serious challenge especially in developing countries where technology and skilled personnel has been found wanting. In developing world, waste stabilisation pond (WSP) has been widely used especially where land is abundant and climate is favourable especially temperature and sunlight [1]. The scarcity of water resources has prompted the alternatives of reusing wastewater especially for agricultural purposes [1]. Many countries in tropical climates use WSP for wastewater treatment. For instance Tanzania, Kenya, Malawi, Uganda, Zambia, Botswana, and Zimbabwe utilise this system. However, many of these systems have been performing below the required standards. The reasons are being lack of proper operation and maintenance, improper positioning of inlet and outlet and sludge accumulation amongst others [2]. WSP systems are relatively low in operation and maintenance costs. In Tanzania, [3] evaluated the efficiency of waste stabilisation ponds in Swaswa, Dodoma municipality. The results indicated very low removal efficiency for most of the parameters evaluated. The system recorded no removal of Biochemical Oxygen Demand (BOD), Total Dissolved Solids (TDS) and Electrical Conductivity (EC) with efficiency as low as $26.7 \%$ recorded. Only turbidity was removed at the highest efficacy of $98.8 \%$. Low efficiency was attributed to incomplete construction of Swaswa system where the third stage of maturation was missing. Reference [4] conducted a study on factors contributing to the inadequate performance of Gaza Waste Water Treatment system. A decrease in the efficiency was attributed to the increase in the organic loading that exceeded treatment plant design capacity, inaccurate design parameters and inadequate operation. Overall poor system performances can be influenced by inefficient hydraulic performances, short circuiting, sludge accumulation and flow velocities [5].

Most previous studies have not included pond geometry, sludge accumulation and drogue to analysis hydraulic efficiency. In addition there are few or no studies that have incorporated the performances of individual units in the treatment system but included only the overall performances.

Over the past years, Botswana has experienced an increase in water demand due to the rapidly growing population. Household water connections generate wastewater that should be discharged safely into the environment. This has led to wastewater treatment facilities being constructed in the country. The treatment systems in the country are mostly waste stabilisation ponds. Palapye WSP system was commissioned in 1997 for treating sewage from domestic and industrial wastewater. Treated effluent is discharged into the catchment area of tributaries that drain into Lotsane River which is dammed downstream.

The aim of this study was to investigate the performance efficiency of the $\mathrm{Pa}$ - 
lapye wastewater treatment plant efficiency. The associated objective was to investigate the hydraulic efficiency and performance efficiency of Palapye waste stabilisation ponds.

\section{Materials and Methods}

\subsection{Study Site}

Palapye is situated almost halfway between Francistown and Gaborone in Central District at elevation $919 \mathrm{~m}$ in Botswana. Its geographic location is latitude $-22^{\circ} 33^{\prime} 00^{\prime \prime}$ and longitude $27^{\circ} 08^{\prime} 00^{\prime \prime}$. The 2011 housing and population census was 36, 211. The Palapye wastewater treatment system is comprised of 1 anaerobic pond, 3 facultative ponds and 6 maturation ponds (Figure 1). The system treats inflow averaging $4507 \pm 214 \mathrm{~m}^{3} /$ day and the pond are laid in series. The system was commissioned in 199 for population equivalent of 34740 . The average annual daily temperature for the area during the period 2015 to 2018 was $29.25^{\circ} \mathrm{C} \pm 3.7^{\circ} \mathrm{C}$ and average annual night temperature was $12.58^{\circ} \mathrm{C} \pm 4.5^{\circ} \mathrm{C}$. The minimum and maximum annual daily temperatures were $23^{\circ} \mathrm{C}$ and $34^{\circ} \mathrm{C}$ respectively. The minimum and maximum annual night temperatures were $6^{\circ} \mathrm{C}$ and $17^{\circ} \mathrm{C}$ respectively. The wind speed blowing from Easterly to Westerly direction is $6 \mathrm{~km} /$ hour.

\subsection{Sampling}

Grab samples were collected from both inlet and outlet points of the system or for each pond. Samples were placed into $1 \mathrm{~L}$ of either polyethylene or glass bottles depending on the parameters to be analysed. The bottles were first cleaned and rinsed with Deionised (DI) water and then with dilute hydrochloric acid and preserved as recommended by American Public Health Association (APHA) 1998 Standard Methods for the Examination of Water and Wastewater. Samples were preserved in ice box during transportation before analysis.

\subsection{Evaluation of Performance Efficiency}

Some physiochemical and microbiological parameters (E. coli, Total Coliforms, and Fecal Coliforms) were analysed according to Standard Methods (APHA,

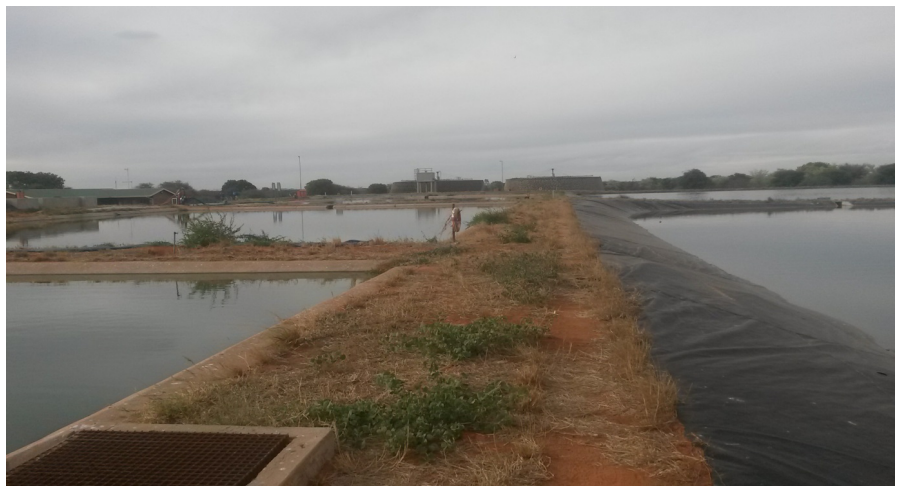

Figure 1. Satellite image view of Palapye wastewater treatment facility. 
1998). Some of the samples were either sent to Department of Water Affairs in Gaborone or Betach (PTY) LTD Laboratories in Francistown for quality cheque. Temperature, $\mathrm{pH}$, TDS, and EC were analysed at site using portable multiparameter Testr $^{\mathrm{TM}} 35$ series meter supplied by Thermo Fisher Scientific. Turbidity was analysed using DR 900 multiparameter portable colorimeter, supplied by $\mathrm{HACH}$, United States of America. Sampling bottles were washed and sterilized in the autoclave. Heat tape was used for verification of equipment for sterilisation. Faecal coliforms (FC) were enumerated by the Membrane Filtration (MF) technique, as per APHA (1998) and the results expressed in Colony Forming Units (CFU) per $100 \mathrm{~mL}$. Enumeration was done in Membrane Lactose Glucuronide Agar (MLGA). Inoculated plates were incubated at $44^{\circ} \mathrm{C} \pm 0.5^{\circ} \mathrm{C}$ for 24 hours. All benches where bacteriological testing was conducted were cleaned and disinfected with $70 \%$ ethanol solution. A $100 \mathrm{~mL}$ sample was filtered through $0.45 \mu \mathrm{m}$ membrane filter paper. The filter paper was placed on a specific media designed to allow colonies of the indicator organisms to grow. After an incubation period the colonies were counted and the results recorded.

The percent removal efficiency was calculated using the following formula:

$$
\% \text { Removal }=\frac{C_{i}-C_{e}}{C_{i}} \times 100 \%
$$

where: $C_{i}$ is the concentration of the influent.

$C_{e}$ is the concentration of the effluent.

\subsection{Evaluation of Hydraulic Performance}

The following parameters were investigated to assess the hydraulic performance of the system.

\subsubsection{Hydraulic Retention Time}

The design retention time was obtained from the detailed design by the Design Engineer. The effective hydraulic retention time was based on pond dimensions, that is, length, width and effective depth. The effective depth was determined by subtracting sludge blanket depth from design depth. The average flow for the system was calculated from inflow rates recorded over time. In determining actual retention time, a drogue method was used to assess the actual hydraulic retention time (HRT) of different units. Five runs were conducted for each pond between October 2016 and February 2017. A replicate of five oranges per run were placed at the inlet of each pond. Time taken by each orange to travel from inlet point to outlet position was recorded and the average time calculated thereafter. Drogue locations were noted at varying intervals, depending on the velocity of their travel. A number of attempts had to be abandoned due to poor weather conditions and scum on the pond surface that interfered with the movement of the floats.

\subsubsection{Pond Geometry}

The physical characteristics including the shape, volume, inlet to outlet align- 
ment, depth of each pond were determined through field survey data. Length to width ratio, inlet and outlet depth was determined using measuring tape and calibrated ruler. Some measurements were taken and average values calculated. Pond shape, inlet and outlet positions were established by visual observations. The pond dimensions were determined by measuring the length and width of each pond.

\subsubsection{Sludge Depth Measurements}

Sludge depth in each pond was measured on three occasions, between June and August 2017, using the white towel method described by [6] and [5] using a 3.5 $\mathrm{m}$ measuring stick. The white towel test was chosen because it was economical, reliable, and the results were easy to interpret. The ponds were divided into grid sections spaced at $3 \mathrm{~m}$ by $3 \mathrm{~m}$. There were a total of 169 measuring points for anaerobic pond and 104 points for facultative ponds 1, 2 and 3. For maturation ponds there were 810 measuring points. The sludge stick was lowered vertically into the pond until it reached the sludge layer. When raising the stick, trapped particles were observed in the white towel up to the level of the sludge blanket depth. By subtracting the sludge depth from the pond depth, the level of sludge in the pond could be estimated.

\subsection{Data Analysis}

Graphs were prepared using Microsoft Excel 2010. Statistical analysis such as mean and standard deviations were also calculated using Microsoft Excel 2010.

\section{Results and Discussion}

\subsection{Hydraulic Retention Time}

Table 1 compares design, effective and actual retention times of each pond in the system. The results indicate that for anaerobic pond $\left(\mathbf{A}_{1}\right)$, design, effective and actual HRTs were $22.8 \mathrm{hrs}, 2.64$ hours and 1.2 hours respectively. In the case of the three facultative ponds, design HRT was 22.8 hours. Effective HRT was increasing as 2.39 hour, 3.96 hours and 4.2 hours respectively, for $F_{1}, F_{2}$ and $F_{3}$ ponds. The actual HRT were similar ranging between 1.6 to 1.8 days. Total HRTs for the system were 20 days, 7.1 days and 21.6 days respectively, being design, effective and actual values.

Table 1. Effective and design retention time for each pond.

\begin{tabular}{|c|c|c|c|c|c|c|c|c|c|c|c|}
\hline Ponds & $\mathrm{A}_{1}$ & $\mathrm{~F}_{1}$ & $\mathrm{~F}_{2}$ & $\mathrm{~F}_{3}$ & $\mathbf{M}_{1}$ & $\mathbf{M}_{2}$ & $\mathrm{M}_{3}$ & $\mathbf{M}_{4}$ & $\mathbf{M}_{5}$ & $\mathrm{M}_{6}$ & Total (d) \\
\hline Dimensions (m) & $42 * 42 * 4$ & $42 * 33 * 2$ & $42 * 33 * 2$ & $42 * 33 * 2$ & $92 * 84^{*} 1.5$ & $92^{*} 84^{*} 1.5$ & $84^{*} 48^{*} 1.5$ & $84^{*} 48^{*} 1.5$ & $84^{*} 48^{*} 1.5$ & $84^{*} 48^{*} 1.5$ & \\
\hline Design HRT (hr or d) & $\begin{array}{c}22.8 \\
\mathrm{hr}\end{array}$ & $\begin{array}{c}22.8 \\
\mathrm{hr}\end{array}$ & $\begin{array}{c}22.8 \\
\mathrm{hr}\end{array}$ & $\begin{array}{c}22.8 \\
\mathrm{hr}\end{array}$ & $\begin{array}{c}2.72 \\
\mathrm{~d}\end{array}$ & $\begin{array}{c}2.72 \\
\mathrm{~d}\end{array}$ & $\begin{array}{c}2.72 \\
\mathrm{~d}\end{array}$ & $\begin{array}{c}2.72 \\
\mathrm{~d}\end{array}$ & $\begin{array}{c}2.72 \\
\mathrm{~d}\end{array}$ & $\begin{array}{c}2.72 \\
\mathrm{~d}\end{array}$ & 20 \\
\hline Effective HRT (hr or d) & $\begin{array}{c}2.64 \\
\mathrm{hr}\end{array}$ & $\begin{array}{c}2.39 \\
\mathrm{hr}\end{array}$ & $\begin{array}{c}3.96 \\
\mathrm{hr}\end{array}$ & $\begin{array}{l}4.2 \\
\mathrm{hr}\end{array}$ & $\begin{array}{c}1.6 \\
\mathrm{~d}\end{array}$ & $\begin{array}{c}1.6 \\
\mathrm{~d}\end{array}$ & $\begin{array}{c}0.84 \\
\mathrm{~d}\end{array}$ & $\begin{array}{c}0.84 \\
\mathrm{~d}\end{array}$ & $\begin{array}{c}0.84 \\
\mathrm{~d}\end{array}$ & $\begin{array}{c}0.84 \\
\mathrm{~d}\end{array}$ & 7.1 \\
\hline Actual HRT (d) & 1.2 & 1.6 & 1.8 & 1.6 & 2.8 & 2.8 & 3 & 3.6 & 1.8 & 1.4 & 21.6 \\
\hline
\end{tabular}


In Table 1, a dramatic reduction was observed between design and effective retention times for the anaerobic pond. This could have been due to the accumulation of sludge resulting in the reduction of the pond depth hence short circuiting of wastewater. However, the actual retention time then increased for the same pond as observed through drogue method. The increase in actual HRT could be due to the presence of scum, which was observed floating on the pond. There was also sludge that was observed floating near inlet and outlet points. Scum and sludge obstructed and delayed the movement of the floats in the pond hence increasing the time of travel between the inlet and outlet points. The same scenario was observed in facultative ponds where effective HRT reduced compared to design HRT and then an increase in actual HRT. Aquatic plants were observed growing in these ponds which hampered the movement of drogue contributing to longer HRT. In the case of maturation ponds, the variations between design, effective and actual HRTs were not much higher, ranging between 1.2 to 3.6 days. The findings for drogue tracking in this study were lower compared to the study reported by [7] where significant short circuiting was observed because of the wrong positioning of the inlet and outlet points. This was reported to have caused influent to flow rapidly to the outlet resulting in the mean actual retention time being shorter than the effective detention time. However drogue method measured the surface retention time and did not include the direct measurement of the internal fluid flow patterns within the ponds. In addition, the method is affected by wind either across or in the opposite direction of flow. Reference [8] reported that winds are a predominant factor in WSP performance, especially wind direction. In this study, the actual HRT was found to be longer due to the circulation in the transverse direction generated in the pond when wind direction was perpendicular to the inflow direction. It was observed that in some of the units, the direction of flow was opposite to the wind direction, hence impeding velocity of the floats. A study conducted by [9] had HRT of 37 days which increased to 62 days as the system was under-loaded. This was different from the findings of this study where design HRT was 20 days and reduced to 7.1 days. It can be concluded that the effective and design retention times for PWTP differ due to reduction of pond volumes. These findings are similar to report by [10] where it was observed that effective volume differs considerably between ponds which lead to inconsistency between the two values of retention times.

\subsection{Pond Geometry}

\subsubsection{Length to Width Ratio}

The length to width ratios were ranging between $1: 1$ to $1.3: 1$ and $1.1: 1$ to $1.75: 1$ for facultative and maturation ponds respectively (Table 2). In a study conducted by [10], it was observed that ponds with larger length to width ratios had less short circuiting effects. This is true for this study where facultative ponds had lower effective retention time, which could have been due to short circuiting 
Table 2. Length to width ratios of the different ponds in the study.

\begin{tabular}{ccccccccccc}
\hline Pond & $\mathrm{A}_{1}$ & $\mathrm{~F}_{1}$ & $\mathrm{~F}_{2}$ & $\mathrm{~F}_{3}$ & $\mathrm{M}_{1}$ & $\mathrm{M}_{2}$ & $\mathrm{M}_{3}$ & $\mathrm{M}_{4}$ & $\mathrm{M}_{5}$ & $\mathrm{M}_{6}$ \\
\hline $\begin{array}{c}\mathrm{L}: \mathrm{W} \\
\text { Ratio }\end{array}$ & $1: 1$ & $1.3: 1$ & $1.3: 1$ & $1.3: 1$ & $2: 1$ & $1.1: 1$ & $1.1: 1$ & $1.75: 1$ & $1.75: 11$ & $1.75: 1$ \\
\hline
\end{tabular}

of flow in these ponds. As for maturation ponds, lengths to width ratio ranged between 1.1:1 and 2:1. Two of the ponds had a ratio of 1.1:1 with the remaining four being 2:1 or nearly, which was similar to the recommend values in most cases.

Higher L:W ratio shifts the pond towards plug flow conditions, which is associated with improved hydraulic performance [11]. It has been reported by [2] that the higher the L:W ratio, the higher the hydraulic efficiency, but only to a certain level. The same authors report that anaerobic and primary facultative ponds have L:W ratio of less than 3 to minimise sludge accumulating and organic over loading near the inlet. They report that secondary facultative and maturation ponds can have large L:W ratio of 10 to 20 to approach plug flow residence pattern. $\mathrm{L}: \mathrm{W}$ ratio of both anaerobic and facultative ponds were less than 3, (ranging between 1:1 and 1.3:1), these values were very low and could have contributed to low hydraulic efficiencies. The ratio for maturation ponds was much lower than recommendation by [2] therefore plug flow residence pattern could not be approached by the system. However, the same authors report that there is inconsistency in reports on the $\mathrm{L}$ : $\mathrm{W}$ ratios with different authors having different ratios.

\subsubsection{Inlet and Outlet Positions}

Inlet and outlet positions for the system are shown in Figure 2. For $A_{1}$, the inlet and outlet are placed on the same side whereas $F_{1}$ and $F_{2}$ the inlets and outlets are placed on opposite sides and adjacent sides for $F_{3}$. For $M_{1}, M_{2}, M_{3}, M_{4}$ and $M_{5}$ the inlets and outlets are on adjacent sides but on opposite sides for $M_{6}$. Reference [12] recommended that inlet and outlet should not be placed on opposite sides to prevent channelling and short circuiting. The arrangements in $A_{1}, F_{1}, F_{2}$ and $\mathrm{M}_{6}$ could promote channelling and hence short-circuiting of wastewater resulting in poor hydraulic efficiency and poor overall performance. Though the actual HRTs of $F_{1}$ to $F_{2}$ (all facultative) were similar despite inlets and outlets located in opposite directions, the differences were pronounced in maturation ponds. $M_{1}, M_{2}, M_{3}, M_{4}$ and $M_{5}$ had higher HRTs than $M_{6}$ whose inlet and outlets were directly on opposite sides hence a high chance of channelling.

\subsubsection{Inlet and Outlet Depths}

Inlet and outlet depth varied from pond to pond. The recommended outlet depths by [13] are $300 \mathrm{~mm}, 600 \mathrm{~mm}$ and $50 \mathrm{~mm}$ respectively for anaerobic, facultative and maturation ponds. Table 3 indicates that except $F_{2}$ the rest of the units, $A_{1}, F_{1}, F_{3}$ and all the maturation ponds complied with the recommendation by [13]. Reference [14] states that outlets should be submerged at a certain depth to minimize short circuiting. The findings in this study suggest that except 


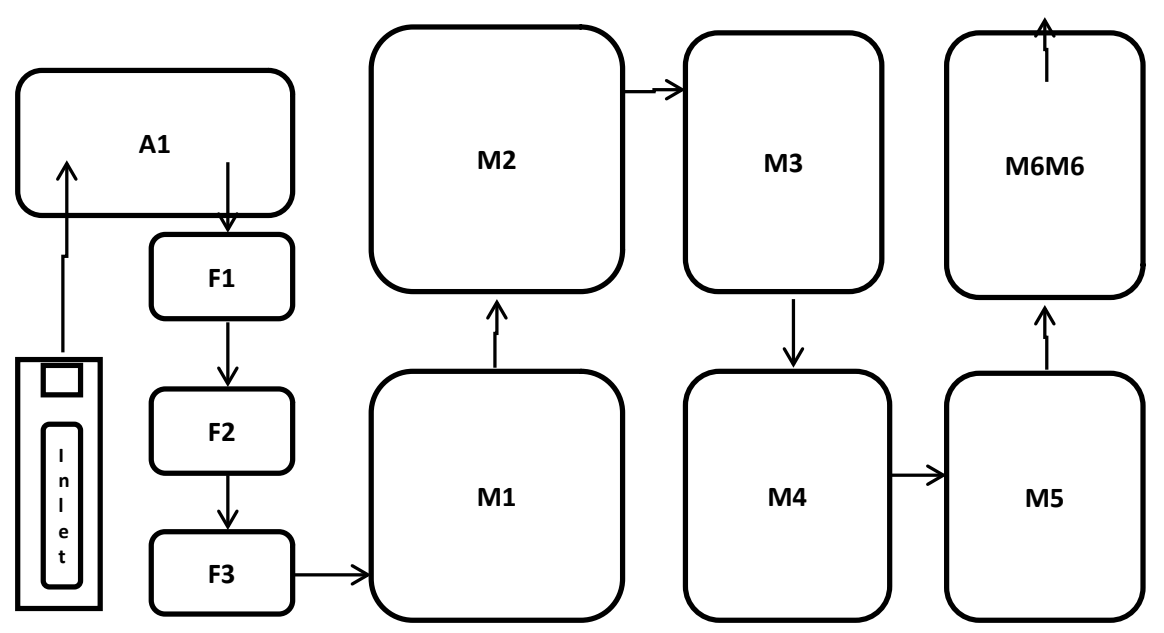

Figure 2. Inlet and outlet positions of the treatment system.

Table 3. Inlet and outlet depth for each pond.

\begin{tabular}{ccccccccccc}
\hline Pond & $\mathrm{A}_{1}$ & $\mathrm{~F}_{1}$ & $\mathrm{~F}_{2}$ & $\mathrm{~F}_{3}$ & $\mathbf{M}_{1}$ & $\mathbf{M}_{2}$ & $\mathbf{M}_{3}$ & $\mathbf{M}_{4}$ & $\mathbf{M}_{5}$ & $\mathbf{M}_{6}$ \\
\hline $\begin{array}{c}\text { Inlet } \\
(\mathrm{mm})\end{array}$ & 600 & 600 & 510 & 510 & 700 & 1200 & 1200 & 1200 & 700 & 600 \\
$\begin{array}{c}\text { Outlet } \\
(\mathrm{mm})\end{array}$ & 600 & 600 & 510 & 700 & 115 & 1200 & 1200 & 700 & 600 & $\begin{array}{c}\text { Outlet } \\
\text { pipe }\end{array}$ \\
\hline
\end{tabular}

$\mathrm{F}_{2}$ the rest of the units $\left(\mathrm{A}_{1}, \mathrm{~F}_{1}, \mathrm{~F}_{3}\right.$ and all the maturation ponds) will not experience channelling of wastewater.

\subsection{Sludge Blanket Height}

The sludge blanket heights in each pond are shown in Table 4. The results indicate that sludge blanket heights were high in the first four ponds and there was none in the maturation ponds. The heights decreased from $A_{1}$ to $F_{3}$. This was expected as these ponds receive influent which has more solids than the maturation ponds and as such the solids settle first in anaerobic ponds followed by facultative ponds. The solids will settle immediately and be biodegraded hence the formation of sludge. There was a reduction in total volume due to sludge height as compared to the maturation ponds where sludge accumulation was not observed. This study is comparable to that conducted by [7] where the design volume of the anaerobic pond was $1285 \mathrm{~m}^{3}$ and reduced to $657 \mathrm{~m}^{3}$ effective volume. This was attributed to continued accumulation of sludge (51\% volume reduction). Similar results were reported by [15]. After operating for 15 years without desludging, the volume of anaerobic pond had reduced by $55.7 \%$ due to accumulation of sludge.

In this study, volume reductions were $90 \%, 78 \%, 76 \%$ and $60 \%$ respectively, for $A_{1}, F_{1}, F_{2}$ and $F_{3}$. Such large reductions were expected as the ponds have been in operation for over 20 years without desludging. The presence of sludge bench was noticeable near inlet and outlet points indicating the presence of sludge in the ponds therefore decreasing the effective HRT and overall performance of the system. 
Table 4. Sludge measurement heights for the different units.

\begin{tabular}{ccccccccccc}
\hline Ponds & $\mathrm{A}_{1}$ & $\mathrm{~F}_{1}$ & $\mathrm{~F}_{2}$ & $\mathrm{~F}_{3}$ & $\mathrm{M}_{1}$ & $\mathrm{M}_{2}$ & $\mathrm{M}_{3}$ & $\mathbf{M}_{4}$ & $\mathbf{M}_{5}$ & $\mathbf{M}_{6}$ \\
\hline Design depth (m) & 4 & 2 & 2 & 2 & 1.5 & 1.5 & 1.5 & 1.5 & 1.5 & 1.5 \\
Actual depth (m) & 0.45 & 0.52 & 0.86 & 0.91 & 1.5 & 1.5 & 1.5 & 1.5 & 1.5 & 1.5 \\
Sludge blanket depth (m) & 3.55 & 1.48 & 1.14 & 1.09 & 0.0 & 0.0 & 0.0 & 0.0 & 0.0 & 0.0 \\
Design volume $\left(\mathrm{m}^{3}\right)$ & 7056 & 2772 & 2772 & 2772 & 11562 & 11562 & 6048 & 6048 & 6048 & 6048 \\
Effective volume $\left(\mathrm{m}^{3}\right)$ & 705 & 623 & 670 & 1108 & 11562 & 11562 & 6048 & 6048 & 6048 & 6048 \\
\hline
\end{tabular}

\subsection{Performance Efficiency}

\subsubsection{Physiochemical Parameters Removal}

Figure 3 shows removal of physio-chemical parameters the system. On average influent BOD concentration was $205 \pm 78 \mathrm{mg} \cdot \mathrm{L}^{-1}$ and the resulting average effluent concentration was $110 \pm 33 \mathrm{mg} \cdot \mathrm{L}^{-1}$, an average removal of $46 \%$. The effluent concentration was above the BOS 93: 2012 threshold limit of discharge into other environments, $30 \mathrm{mg} \cdot \mathrm{L}^{-1}$. Algae growth was observed in some of the ponds which could have exerted BOD concentration during die offs and decaying at the bottom of the units. The same observation was reported by [16] who linked high BOD and TSS in the effluent to mass of algae observed floating in the ponds.

It was observed earlier that the effective HRT was lower compared to design HRT which could have led to less contact time for microbes to degrade BOD. BOD is mostly removed in anaerobic and facultative ponds but it was observed that design HRT for each of the first four ponds was 22.8 hours and the corresponding effective HRT for the same ranged between 2.39 hours to 4.2 hours. This was a higher reduction in residence time, hence channelling and short circuiting effect contributing to inefficiency. This was in agreement with [17] who stated that many systems were found to operate below an optimal level due to reduced retention time. Another contribution on the hydrodynamics could have been due to L:W ratios which ranged between 1:1 to 1.3:1 for the first four ponds, lower than the recommended values of 2:1 to 3:1. Reference [18] reported that for facultative ponds, $\mathrm{L}: \mathrm{W}$ of 2:1 plus provision of baffles increases the pond retention time and BOD removal efficiency. Reference [19] concluded that the efficiency of WSPs in the removal of BOD, COD, TSS can be improved through the addition of baffles to optimise HRT and improve plug flow conditions of the ponds.

On average, influent and effluent COD concentrations were $549 \pm 145 \mathrm{mg} \cdot \mathrm{L}^{-1}$ and $156 \pm 135 \mathrm{mg} \cdot \mathrm{L}^{-1}$ respectively representing a percent removal averaging $72 \%$. The system did not meet the threshold of $150 \mathrm{mg} \cdot \mathrm{L}^{-1}$ though this was high removal of COD. However these results are relatively less compared to other WSPs which can achieve more than $80 \%$ removal as reported by [20]. The results are also comparable to the findings of [21] where influent and effluent concentrations were $424 \mathrm{mg} \cdot \mathrm{L}^{-1}$ and $100 \mathrm{mg} \cdot \mathrm{L}^{-1}$ respectively, a removal efficiency was $76 \%$. High COD levels decrease the amount of dissolved oxygen available for aquatic organisms. Removal of COD is significant in anaerobic ponds which can be 


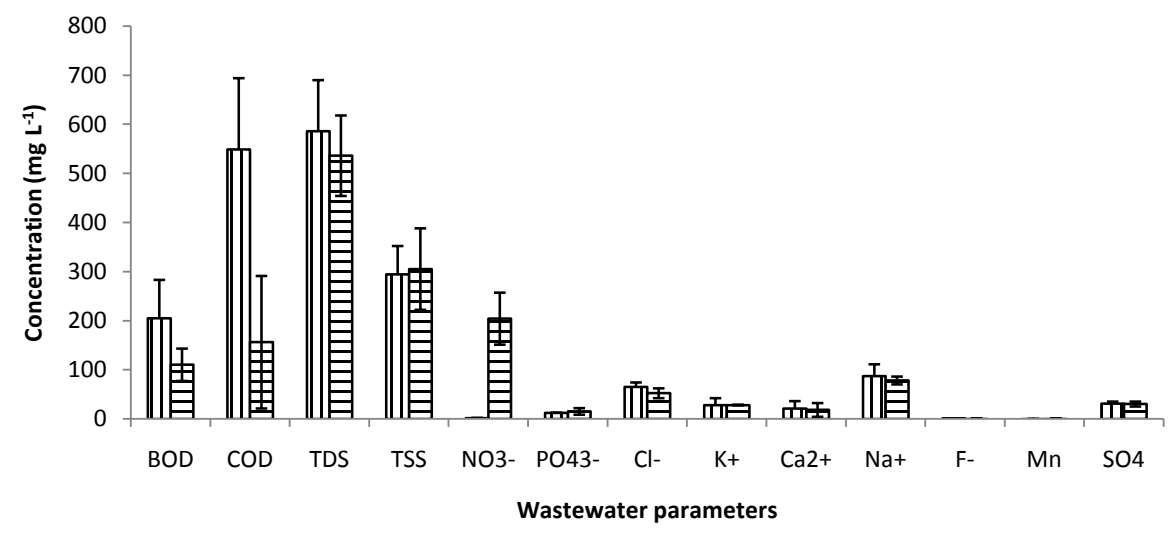

Figure 3. Inlet and outlet physio-chemical parameters from the system.

achieved by an appropriate retention time which was not the case in this study. COD removal has been reported to be due to physical and microbial mechanisms [22]. This is achieved through sedimentation of suspended solids and rapid decomposition in the ponds. But due to low hydraulic efficiency, this contributed to low reduction.

It was observed that TDS concentrations averaged $586 \pm 104 \mathrm{mg} \cdot \mathrm{L}^{-1}$ and $536 \pm$ $82 \mathrm{mg} \cdot \mathrm{L}^{-1}$ in the influent and effluent respectively, which was $8.5 \%$ reduction. Though this was very low removal efficiency, the standard limit of $2000 \mathrm{mg} \cdot \mathrm{L}^{-1}$ was not exceeded. Poor removal was attributed partly to high overloading of the ponds and heavy accumulation of sludge in the primary sedimentation ponds which was the case in this study. High concentrations of TDS reduce water clarity, contributing to a decrease in photosynthesis hence low oxygen supply for biodegradation.

Average TSS concentrations in the influent and effluent were $294 \pm 57 \mathrm{mg} \cdot \mathrm{L}^{-1}$ and $305 \pm 83 \mathrm{mg} \cdot \mathrm{L}^{-1}$ respectively, which was an increase of $3.74 \%$. TSS in wastewater can absorb heavy metals during treatment and introduce heavy metals into the receiving environment [20]. Since it was observed that short circuiting and channelling could have been taking place, suspended solids did not have enough time to settle hence escaped into the receiving environment. An increase of TSS could have been a result of algae die off which were present in the ponds. This was reported by [23] who attributed the increase of TSS in the pond effluent to the presence of algae. The same observation was reported by [24] who concluded in their study in Egypt that the algae present in the ponds were responsible for increasing TSS concentration in the effluent. Reference [12] reported that pond desludging as well as re-positioning of inlet-outlet increased the removal efficiency of both BOD and TSS. Significant removal of TSS can be achieved through disludging as it was observed that the first four ponds had high sludge accumulation hence short circuiting of wastewater resulting in poor TSS settling.

Nitrates had increased in the effluent from an initial average concentration of $1.58 \pm 0.3 \mathrm{mg} \cdot \mathrm{L}^{-1}$ to $203 \pm 53 \mathrm{mg} \cdot \mathrm{L}^{-1}$ in the effluent which was a $99 \%$ increase. The effluent concentration was way above the permissible limit of $50 \mathrm{mg} \cdot \mathrm{L}^{-1}$. The 
increment could have been due to algae die off which exerted nitrates since algae utilise nitrates. Such increase was reported by [20] who observed an increase from $0.4 \mathrm{mg} \cdot \mathrm{L}^{-1}$ to $2.71 \mathrm{mg} \cdot \mathrm{L}^{-1}$. The increase was attributed to the breakdown of organic matter which was oxidised into nitrates. Since high load of organic matter was observed due to high BOD, the same could have happened in this study. This increase might result from nitrification process by nitrifying bacteria in the system [9]. The high nitrate concentration can cause eutrophication on the receiving water bodies.

Similarly, it was observed that there was an increase of phosphate ion in the effluent as the average influent concentration was $12.4 \pm 0.58 \mathrm{mg} \cdot \mathrm{L}^{-1}$ compared to average effluent concentration of $15.0 \pm 6.7 \mathrm{mg} \cdot \mathrm{L}^{-1}$, a $20 \%$ increase. This concentration exceeded the national threshold of discharge into other environments, of $1.5 \mathrm{mg} \cdot \mathrm{L}^{-1}$. It has been reported by [25] that phosphate removal in waste stabilisation pond is highly variable, with an average removal of between $15 \%$ and $50 \%$. The presence of algal blooms in the ponds could have been due to phosphate and nitrates in the wastewater. Algae blooms could prevent sunlight from penetrating down to the underwater in the system therefore hindering the treatment process.

The concentrations of chloride $\left(\mathrm{Cl}^{-}\right)$, calcium $\left(\mathrm{Mg}^{2+}\right)$, potassium $\left(\mathrm{K}^{+}\right)$and sodium $\left(\mathrm{Na}^{+}\right)$ions are as shown in Figure 3. $\mathrm{Cl}^{-}$concentration was $65.4 \pm 9 \mathrm{mg} \cdot \mathrm{L}^{-1}$ in the influent and $52 \pm 10 \mathrm{mg} \cdot \mathrm{L}^{-1}$ in the effluent. The $\mathrm{Cl}^{-}$concentrations are within the national threshold value of $600 \mathrm{mg} \cdot \mathrm{L}^{-1}$. Hong, et al. 2007 studied the effect of increased chloride concentration in wastewater and observed that ammonium nitrogen was not affected but phosphorus and COD removal decreased.

The mean inluent and effluent concentrations values for $\mathrm{K}^{+}$were $27.9 \pm 14$ $\mathrm{mg} \cdot \mathrm{L}^{-1}$ and $28.3 \pm 0.7 \mathrm{mg} \cdot \mathrm{L}^{-1}$ respectively. This shows a very low removal of $\mathrm{K}^{+}$ and the values far exceed the limit discharge of $0 \mathrm{mg} / \mathrm{l}$ allowed into the surface water. Other ions such as $\mathrm{Na}^{+}, \mathrm{Ca}^{2+}, \mathrm{F}^{-} \mathrm{Mn}^{2+}$ and $\mathrm{SO}_{4}^{2-}$ were within the threshold limit and therefore not hazardous to the environment.

Electrical conductivity values were $1355 \pm 45 \mu \mathrm{S} / \mathrm{cm}$ and $519 \pm 65 \mu \mathrm{S} / \mathrm{cm}$ in the influent and effluent respectively, which was an average of $62 \%$ removal (Table 5). The effluent concentration was within the recommended limit of 3000 $\mu \mathrm{S} / \mathrm{cm}$, hence no adverse effect to the environment. The EC levels in the effluent indicate that the effluent is suitable for irrigation and it would pose a low salinity hazard in the soil. High TDS in the incoming influent can contribute to high EC values. TDS in wastewater can be trapped by plants or settles to the bottom of the pond which forms sediment thus helping the reduction of EC concentration. The presence of some plants observed could have contributed to this reduction.

The average $\mathrm{pH}$ in the influent and effluent were $7.03 \pm 0.5$ and $6.87 \pm 0.4$ respectively (Table 5). The effluent $\mathrm{pH}$ is within the permissible limit for discharge into other environments whose range is 6 to 9. It has been reported that in general, wastewater $\mathrm{pH}$ is acidic [26]. Extreme $\mathrm{pH}$ of wastewater is generally 
Table 5. Influent and effluent concentrations for some physiochemical parameters

\begin{tabular}{ccc}
\hline Parameter & Inlet concentration & Outlet concentration \\
\hline $\mathrm{EC}(\mu \mathrm{S} / \mathrm{cm})$ & $1355 \pm 45$ & $519 \pm 65$ \\
$\mathrm{pH}($ units $)$ & $7.03 \pm 0.5$ & $6.87 \pm 0.4$ \\
Turbidity $(\mathrm{NTU})$ & $415 \pm 1$ & $277 \pm 2$ \\
Temperature $\left({ }^{\circ} \mathrm{C}\right)$ & $25.3 \pm 3$ & $25.3 \pm 0.14$ \\
\hline
\end{tabular}

not acceptable because it affects survival of aquatic life. In addition, high $\mathrm{pH}$ interferes with the optimum operation of wastewater treatment system. At acidic conditions, heavy metals tend to exist as free metal ions while around neutral conditions, some precipitate as hydroxides or other insoluble species if the appropriate co-ion is available [27]. At high $\mathrm{pH}$ most of the metals become insoluble and accumulate in the sludge and sediments. At low $\mathrm{pH}$ most of the metals become soluble and available, therefore could be hazardous to the environment [28]. This study indicates that the presence of algae in the ponds did not consume most of the carbon dioxide during photosynthesis which could have elevated $\mathrm{pH}$ during dissociation of carbonate and bicarbonate ions. Instead, high concentration of carbon dioxide neutralised the wastewater. It has been reported that for ideal anaerobic conditions for biological activity, the $\mathrm{pH}$ should range between 6.6 and 7.6 but should not drop below 6.2 [16]. Below 6.2, anaerobic bacteria cannot function. Above $\mathrm{pH} 9$, it has been reported that the efficiency of anaerobic system drops rapidly. The influent $\mathrm{pH}$ was favourable to anaerobic conditions, therefore a possibility of degradation of organic matter into favourable conditions.

Average turbidity concentrations in the influent and effluent were $415 \pm 1$ NTU and $277 \pm 2$ NTU respectively which was $33.3 \%$ reduction. This was a low achievement as this value was above the threshold limit of $30 \mathrm{mg} \cdot \mathrm{L}^{-1}$. Observed algae growing in the ponds could have contributed to high turbid effluent. Poor hydraulic efficiency of the system could have contributed to poor settling of flocs and suspensions. High effluent TSS concentration observed earlier could also have contributed to high turbidity. Desludging of the ponds could increase HRT and improve the hydraulic efficiency of the system and overall performance on turbidity removal.

The average influent and effluent temperatures were $25.4 \pm 3$ and $25.3^{\circ} \mathrm{C} \pm$ $0.1^{\circ} \mathrm{C}$ respectively. The maximum and minimum values (not shown) in the effluent were $33.3 \pm 2.6$ and $17.0^{\circ} \mathrm{C} \pm 1.6^{\circ} \mathrm{C}$. It has been reported that working temperature for anaerobic conditions is between $25^{\circ} \mathrm{C}$ to $40^{\circ} \mathrm{C}$ and that anaerobic conditions decrease rapidly when temperatures are below $15^{\circ} \mathrm{C}$ [16]. The minimum value was higher than $15^{\circ} \mathrm{C}$ which could negatively affect anaerobic conditions in the anaerobic and facultative ponds. But night temperatures during cold months can be as low as $6^{\circ} \mathrm{C}$ which can reduce or even inactivate anaerobic conditions. 


\subsubsection{Coliforms Removal}

The influent and effluent bacteriological results are shown in Figure 4. The average influent and effluent $E$. coli concentrations were $4.6 \pm 0.4 \log$ counts and $2.5 \log$ counts respectively, which was a $2.1 \log$ count reduction (45.7\%). Total Coliforms reduced from influent average concentration of $7.3 \pm 0.6 \log$ counts to effluent average concentration of $3.6 \pm 0.01 \log$ counts, a $3.7 \log$ counts reduction (51\%). Similarly, faecal coliforms were reduced from an average influent concentration of $5.9 \pm 0.6 \log$ counts to effluent concentration of $3.5 \pm 0.2 \log$ counts which was an average reduction of $2.4 \log$ counts or $41 \%$ reduction and slightly above the $3 \log$ counts limit. The total coliforms average concentration was within the limit of $4.3 \mathrm{log}$ counts. Pathogen removal usually takes place in maturation ponds as they are shallow and allow light penetration. Deep lagoons are more likely to have anaerobic zones, which have been reported to enhance bacterial survival [24]. TSS in the effluent was found to have increased by $3.74 \%$ that is from influent concentration of $294 \pm 57 \mathrm{mg} \cdot \mathrm{L}^{-1}$ to effluent concentration of $305 \pm 83 \mathrm{mg} \cdot \mathrm{L}^{-1}$. High TSS concentration could have prevented sunlight penetration into the ponds hence low die offs, and poor reduction. It was observed earlier that effective HRT was lower than design HRT which could have contributed to low coliform removal.

Reference [29] reported that during the last three years before reaching the design life, the capability of the system to remove faecal coliforms is reduced continuously. This could be due to increased inflow, high organic loading, improper design criteria particularly maturation ponds. Reference [30] observed that the reduction of faecal coliforms in maturation ponds can be achieved by a combination of many factors, such as increased L:W ratio, reduced dispersion number and increased hydraulic retention time. Reference [31] in their study in CFD (computational fluid dynamic) modelling of baffles for optimizing tropical waste stabilization pond system, indicated that provision of baffles in secondary facultative and primary maturation ponds significantly increases $E$. coli removals. The ponds for this study were not baffled which could have contributed to low removal efficiency. Since the ponds have not been desludged since commissioning, low performance in bacteriological reduction was expected. Total coliforms showed the highest reduction of $51 \%$. The effluent concentration was 3.62 $\pm 0.01 \log$ counts and within the national limit of $4.3 \mathrm{log}$ counts. The $51 \%$ removal is low compared to the findings by [32] who reported efficiency of $98.8 \%$ for total coliforms reduction. An overall average removal of 3.1 logs was observed for total and faecal coliforms, whereas 2.1 log counts were observed in the case of $E$. coli. But overall, the system had achieved reduction of coliforms.

\subsubsection{Performance of Individual Units (Physiochemical)}

The performances of individual units on the reduction of BOD, TDS, COD and $\mathrm{pH}$ are shown in Figure 5. There is less variation in average $\mathrm{pH}$ revealed by the different units. The $\mathrm{pH}$ ranged between 6.84 and 8.3 and was within the 6 to 9 limit. For the protection of the aquatic environment, the $\mathrm{pH}$ should be within 


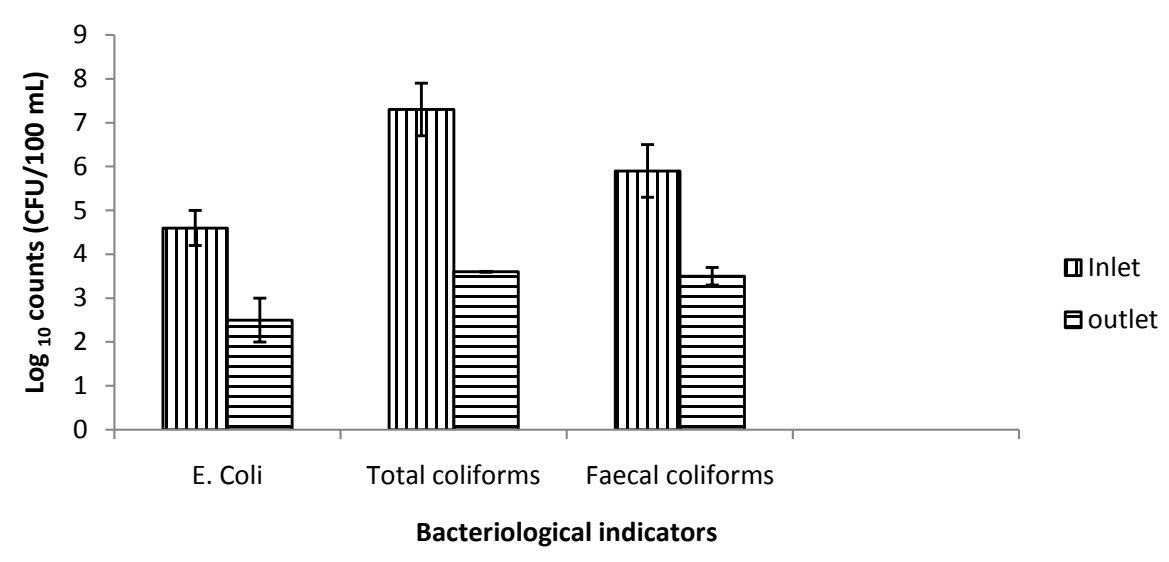

Figure 4. Inlet and outlet bacteriological parameter concentrations.

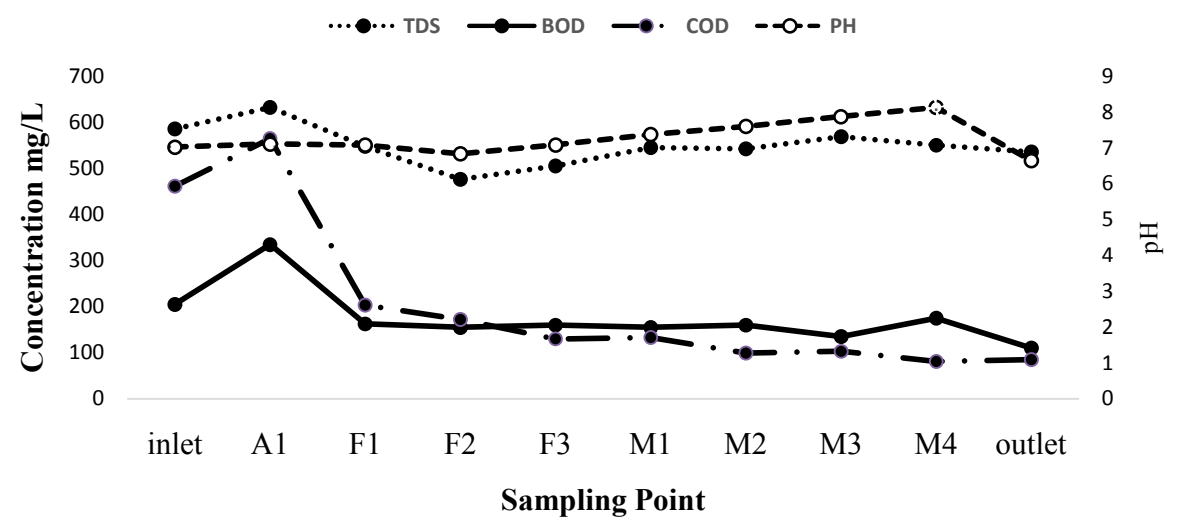

Figure 5. Variations of TDS, BOD, COD and $\mathrm{pH}$ along the treatment system.

the range of 6.5 to 9 units and discharges should not alter the ambient $\mathrm{pH}$ by more than $0.5 \mathrm{pH}$ units in mixing zones [33]. It should be noted that balancing of $\mathrm{pH}$ in the anaerobic pond is critical in optimising the efficiency of anaerobic treatment. Reference [34] reported that optimal $\mathrm{pH}$ should be between 6.6 and 7.6 for helping in the development of methanogenic bacteria.

The mean concentrations of TDS, BOD and COD in each operational unit indicate a reduction as wastewater passed through each pond. There is a noticeable pattern in TDS, BOD, and COD values obtained in $A_{1}$ where there was higher concentration of these parameters than in the influent. This was expected as it is the first pond in the system and the wastewater had to spend some time for treatment. There was marginal decrease in TDS, BOD and COD concentrations in the system from $F_{1}$ to $M_{4}$ (Figure 5). On average, influent BOD was 205 $\mathrm{mg} \cdot \mathrm{L}^{-1}$ and increased to $335 \mathrm{mg} \cdot \mathrm{L}^{-1}$ in $\mathrm{A}_{1}$ effluent, which was a $-63 \%$ removal indicating an increase in concentration. This increase could be attributed to high organic loading in $\mathrm{A}_{1}$. The other reason can be attributed to shorter HRT observed, 2.64 hours instead of design HRT of 22.8. However, a higher reduction was observed in $F_{1}$ where a $172.5 \mathrm{mg} \cdot \mathrm{L}^{-1}$ reduction from $\mathrm{A}_{1}$ was noticed, which was a $51 \%$ removal efficiency. Between $\mathrm{F}_{1}$ and $\mathrm{M}_{2}$, BOD concentration was constant ranging between $162.5 \mathrm{mg} \cdot \mathrm{L}^{-1}$ and $155 \mathrm{mg} \cdot \mathrm{L}^{-1}$ and then dropped to 135 
$\mathrm{mg} \cdot \mathrm{L}^{-1}$ in $\mathrm{M}_{3}$. There was a sharp increase into $\mathrm{M}_{4}$ to $175 \mathrm{mg} \cdot \mathrm{L}^{-1}$, but the effluent concentration dropped to $110 \mathrm{mg} \cdot \mathrm{L}^{-1}$ at the outlet. The sharp increase could have been due to algae die off in the pond which contributed to decay of organic matter hence bacteria needing more oxygen and increased HRT for biodegradation. Overall, BOD removal in facultative ponds $\left(\mathrm{F}_{1}\right.$ to $\left.\mathrm{F}_{3}\right)$ was $175 \mathrm{mg} \cdot \mathrm{L}^{-1}$, a $52 \%$ reduction. As for maturation ponds $\left(\mathrm{M}_{1}\right.$ to outlet), the reduction was $50 \mathrm{mg} \cdot \mathrm{L}^{-1}$, a $31 \%$ reduction. These results slightly contrast those reported by Shalaby et al., (2003) where removal was $22 \%, 57 \%$ and $-9.5 \%$ in anaerobic, facultative and maturation ponds respectively. But comparable with facultative ponds where in both cases $57 \%$ and $52 \%$ removal was observed.

The same pattern was observed for COD, but there was no sharp rise as observed in the case of BOD. There were marginal fluctuations between the ponds, with reductions ranging between $22 \mathrm{mg} \cdot \mathrm{L}^{-1}$ and $43 \mathrm{mg} \cdot \mathrm{L}^{-1}$ and increases between $3 \mathrm{mg} \cdot \mathrm{L}^{-1}$ and $4 \mathrm{mg} \cdot \mathrm{L}^{-1}$. COD removal in $\mathrm{A}_{1}$, facultative ponds and maturation ponds were $-22 \%, 77 \%$ and $35 \%$ respectively. Similarly, the results were slightly comparable to the findings reported by Shalaby et al., (2003) who instead reported efficiencies of $3.3 \%, 63 \%$ and $19.5 \%$ respectively. TDS concentration increased from influent concentration of $586 \mathrm{mg} \cdot \mathrm{L}^{-1}$ to effluent $\mathrm{A}_{1}$ concentration of $632.5 \mathrm{mg} \cdot \mathrm{L}^{-1}$. There were fluctuations observed between facultative and maturation ponds. Overall, TDS concentration was increasing and reducing between the different units. Removal efficiencies between the different units were $-7.9 \%$, $20 \%$ and $-6.0 \%$ respectively, in anaerobic, facultative and maturation ponds. This study indicates that TDS was not removed by system.

\subsubsection{Performance of Individual Units (Microbiological)}

The overall removal of $E$. coli and total coliforms are shown in Figure 6.

It was observed that overall, total coliforms were not removed in anaerobic ponds as both influent and effluent concentrations were 7.4 log counts (Figure 6). An overall reduction of $1.5 \mathrm{log}$ counts was observed in facultative ponds which were a $20.3 \%$ reduction. In maturation ponds, reduction of total coliforms was $2.3 \mathrm{log}$ counts an efficiency of $39.0 \%$ confirming that coliforms are mostly removed in maturation ponds. The overall average effluent concentration was $3.6 \log$ counts which was less than the threshold of $4.3 \log$ counts.

There was no removal observed for $E$. coli in anaerobic pond $\left(\mathrm{A}_{1}\right)$ and the first facultative pond $\left(\mathrm{F}_{1}\right)$, but instead an increase in concentration of $19.1 \%$ was observed. A slight removal was observed at the end of $\mathrm{F}_{3}$ where $8.9 \%$ reduction was observed. A pronounced efficiency was observed in maturation ponds where 2.6 $\log$ count was observed in the effluent from an effluent concentration of $5.1 \mathrm{log}$ counts. This was a reduction of $49 \%$ still revealing that microbes are mostly eliminated in maturation ponds.

\section{Conclusion}

Hydraulic efficiency and performance of Palapye waste stabilisation pond system has been investigated. The results from the current study reveal low hydraulic 


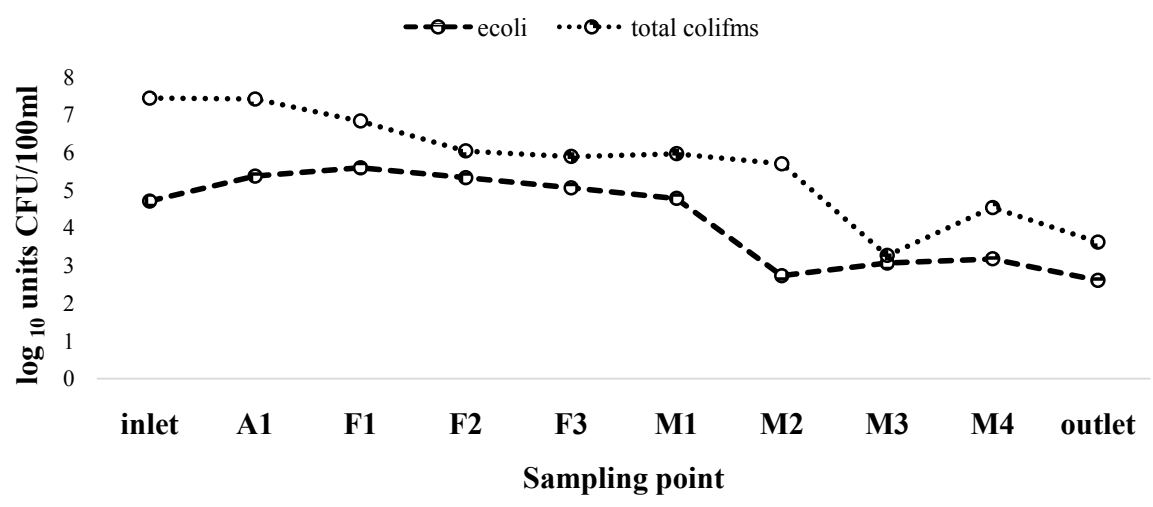

Figure 6. E. coli and total coliforms removal at each operational unit.

efficiency as indicated by reduced effective HRT compared to design HRT for each unit in the system. The overall design HRT was 20 days but reduced to effective HRT of 7.1 days. High sludge accumulation in the ponds reduced pond depths therefore HRT resulting in channelling and short circuiting. The overall impact was reduced performance efficiency of the system that does not comply with some of the discharge limits. Despite, all these it was found that total coliforms and some of the physio chemical parameters were within the discharge limit and faecal coliforms were slightly above the limit of 3 log counts. It was also observed that coliforms are mostly removed in maturation ponds. The Palapye treatment system performance efficiency is better but desludging will even improve both hydraulic and performance efficiency.

\section{Acknowledgements}

We also thank Water Utilities Corporation and their Technical Staff for allowing us to conduct research on their facility and assistance rendered.

\section{Funding}

This work was supported by Botswana International University of Science and Technology through grant initiation programme (grant number 10/2016).

\section{Conflicts of Interest}

The authors declare no conflicts of interest regarding the publication of this paper.

\section{References}

[1] Gruchlik, Y., Linge, K. and Joll, C. (2018) Removal of Organic Micropollutants in Waste Stabilisation Ponds : A Review. Journal of Environmental Management, 206, 202-214. https://doi.org/10.1016/j.jenvman.2017.10.020

[2] Li, M., Zhang, H., Lemckert, C., Roiko, A. and Stratton, H. (2018) On the Hydrodynamics and Treatment Efficiency of Waste Stabilisation Ponds : From a Literature Review to a Strategic Evaluation Framework. Journal of Cleaner Production, 183, 495-514. https://doi.org/10.1016/j.jclepro.2018.01.199 
[3] Mkude, I. and Saria, J. (2014) Assessment of Waste Stabilization Ponds (WSP) Efficiency on Wastewater Treatment for Agriculture Reuse and Other Activities a Case of Dodoma Municipality, Tanzania. Ethiopian Journal of Environmental Studies and Management, 7, 298-304. https://doi.org/10.4314/ejesm.v7i3.9

[4] Nassar, A., Najar, H., Smith, M. and Ghannam, M. (2010) Gaza Wastewater Treatment Plant as a Model for Low Cost Wastewater Treatment Technology in Semi-Arid Environment. Research Journal of Environmental Sciences, 4, 149-157. https://doi.org/10.3923/rjes.2010.149.157

[5] Coggins, L., Ghisalberti, M. and Ghadouani, A. (2017) Sludge Accumulation and Distribution Impact the Hydraulic Performance in Waste Stabilisation Ponds. Water Research, 110, 354-365. https://doi.org/10.1016/j.watres.2016.11.031

[6] Mara, D. (2004) Domestic Wastewater Treatment in Developping Countries. Earthscan, London, United Kingdom.

[7] Fyfe, J., Hagare, D. and Sivakumar, M. (2016) Dairy Shed Effluent Treatment and Recycling: Effluent Characteristics and Performance. Journal of Environmental Management, 180, 133-146. https://doi.org/10.1016/j.jenvman.2016.04.058

[8] Wang, Z., Dong, J., Liu, L., Zhu, G. and Liu, C. (2013) Screening of Phosphate-Removing Substrates for Use in Constructed Wetlands Treating Swine Wastewater. Ecological Engineering, 54, 57-65. https://doi.org/10.1016/j.ecoleng.2013.01.017

[9] Gad, M. and Abdalla, A. (2017) Fate of Heavy Metals and Nutrients in Waste Stabilisation Ponds in Arid Zones. Journal of Engineering Sciences, 45, 1-16.

[10] Persson, J. (2000) The Hydraulic Performance of Ponds of Various Layouts. Urban Water, 2, 243-250. https://doi.org/10.1016/S1462-0758(00)00059-5

[11] Mara, D. (2003) Anaerobic Waste Stabilization Ponds : A Low-Cost Contribution to a Sustainable Wastewater Reuse Cycle. Applied Microbiology and Biotechnology, 109, 214-252.

[12] Peña, M., Mara, D. and Sanchez, A. (2000) Dispersion Studies in Anaerobic Ponds: Implications for Design and Operation. Water Science and Technology, 42, 273-282. https://doi.org/10.2166/wst.2000.0660

[13] Mara, D. (2016) Design Manual for Waste Stabilization Ponds in Mediterranean Countries, 2016.

[14] Water Environmental Federation (2018) Effect of the Location of the Inlet and Outlet Structures on Short-Circuiting. Experimental Investigation, 78, 580-589.

[15] Bouza-dea, R. (2013) Distribution and Spatial Variability of Sludges in a Wastewater Stabilization Pond System without Desludging for a Long Period of Time. Ecological Engineering, 50, 5-12. https://doi.org/10.1016/j.ecoleng.2012.07.010

[16] Türker, U., Okaygün, M. and Almaqadma, J. (2009) Impact of Anaerobic Lagoons on the Performance of BOD and TSS Removals at the Haspolat (Mia Milia) Wastewater Treatment Plant, DES, 249, 403-410.

[17] Li, M., Zhang, H., Lemckert, C., Lu, Z., Lei, L. and Stratton, H. (2013) Three-Dimensional Investigation of Retention Time Distribution of Waste Stabilisation Ponds. 20 th International Congress on Modeling and Simulation, Adelaide, 1-6 December 2013, 1-6.

[18] Matagi, S., Swai, D. and Mugabe, R. (1998) A Review of Heavy Metal Removal Mechanisms in Wetlands. African Journal of Tropical Hydrobiology and Fisheries, 8, 23-35.

[19] Farzadkia, M., Ehrampoush, M., Sadeghi, S., Kermani, M. and Taghi, M. (2014) 
Performance Evaluation of Wastewater Stabilization Ponds in Yazd-Iran. Environmental Health Engineering and Management Journal, 1, 7-12.

[20] Nkegbe, E., Emongar, V. and Koorapetsi, I. (2005) Assessment of Effluent Quality at Glen Valley Wastewater Treatment Plant. Journal of Applied Sciences, 5, 647-650. https://doi.org/10.3923/jas.2005.647.650

[21] Mburu, N., Tebitendwa, M., Van Bruggen, Rousseau, L. and Lens, L. (2013) Performance Comparison and Economics Analysis of Waste Stabilization Ponds and Horizontal Subsurface Flow Constructed Wetlands Treating Domestic Wastewater: A Case Study of the Juja Sewage Treatment Works. Journal of Environmental Management, 128, 220-225. https://doi.org/10.1016/j.jenvman.2013.05.031

[22] Hellal, M. (2013) Municipal Wastewater Treatment in Horizontal and Vertical Flows Constructed Wetlands. Ecological Engineering, 61, 460-468.

https://doi.org/10.1016/j.ecoleng.2013.10.010

[23] Dias, D., Possmoser-nascimento, E., Rodrigues, J. and Von Sperling, M. (2014) Overall Performance Evaluation of Shallow Maturation Ponds in Series Treating UASB Reactor Effluent: Ten Years of Intensive Monitoring of a System in Brazil. Ecological Engineering, 71, 206-214. https://doi.org/10.1016/j.ecoleng.2014.07.044

[24] Abdel-shafy, H. and Salem, M. (2007) Efficiency of Oxidation Ponds for Wastewater in Eygpt. In: Zaidi, M.K., Ed., Wastewater Reuse-Risk Assessment, Decision-Making and Environmental Security, Springer, Berlin, 175-184.

[25] Powell, N., Shilton, A., Pratt, S. and Chisti, Y. (2008) Factors Influencing Luxury Uptake of Phosphorus by Microalgae in Waste Stabilization Ponds. Environmental Science \& Technology, 42, 5958-5962. https://doi.org/10.1021/es703118s

[26] Imran, H. (2005) Wastewater Monitoring of Pharmaceutical Industry: Treatment and Reuse Options. Electronic Journal of Environmental, Agricultural and Food Chemistry, 4, 994-1004.

[27] Pearson, H., Mara, D. and Smallman, J. (1987) Factors Determining Algal Populations in Waste Stabilization Ponds and the Influence of Algae on Pond Performance. Water Science \& Technology, 19, 131-140. https://doi.org/10.2166/wst.1987.0137

[28] Kavitha, R., Murthy, V., Makam, R. and Asith, K. (2012) Physico-Chemical Analysis of Effluents from Pharmaceutical Industry and Its Efficiency Study. International Journal of Engineering Research, 2, 103-110.

[29] Afifi, S. (2005) Evaluation of Technical Performance of Beit-Lahia Wastewater Treatment Plant in the Northern Gaza Strip-Palestine. 2nd International Conference on the Palestinian Environment, 1, 152-164.

[30] Bracho, N., Lloyd, B. and Aldana, G. (2006) Optimisation of Hydraulic Performance to Maximise Faecal Coliform Removal in Maturation Ponds. Water Research, 40, 1677-1685. https://doi.org/10.1016/j.watres.2006.02.007

[31] Shilton, A. and Mara, D. (2005) CFD (Computational Fluid Dynamics) Modelling of Baffles for Optimizing Tropical Waste Stabilization Pond Systems. Water Science \& Technology, 51, 103-106. https://doi.org/10.2166/wst.2005.0438

[32] Ghazy, M., El-senousy, W., Abdel-aatty, A. and Kamel, M. (2008) Performance Evaluation of a Waste Stabilization Pond in a Rural Area in Egypt. American Journal of Environmental Sciences, 4, 316-325. https://doi.org/10.3844/ajessp.2008.316.325

[33] Longe, O. and Ogundipe, A. (2010) Assessment of Wastewater Discharge Impact from a Sewage Treatment Plant on Lagoon Water, Lagos, Nigeria. Research Journal of Applied Sciences, Engineering and Technology, 2, 274-282. 
[34] Menya, E., Wangi, G., Amanyire, F. and Ebangu, B. (2013) Design of Waste Stabilization Ponds for Dairy Processing Plants in Uganda. Agricultural Engineering International: CIGR Journal, 15, 198-207. 